\title{
BRANDING SERIAL KKPK: TINJAUAN PADA MINAT LITERASI ANAK-ANAK
}

\author{
Redjeki Agoestyowati \\ Institut Ilmu Sosial dan Manajemen STIAMI \\ astie_kerto@yahoo.com
}

\begin{abstract}
Abstrak. Hasil survey indeks literasi yang diterbitkan oleh Central Connecticut State of University (CCSU) pada Maret tahun 2016 memperlihatkan dari 61 negara yang disurvei, peringkat literasi Indonesia ada di uruta ke 60. Riset yang juga menilai reading assesment score untuk anak di bawah usia 18 tahun itu, seperti yang dikutip dari laman CCSU.edu (diakses 4/6/2017) menunjukkan bahwa kemampuan anak-anak Indonesia memahami bacaan juga sangat rendah.

Kemampuan literasi anak-anak bisa sangat tinggi. Itu artinya, keluarga dan bentuk pendidikan usia dini memberi pengaruh sangat besar terhadap tinggi-rendahnya kemampuan literasi seorang anak.

Penerbit Mizan melalui lini buku KKPK/ Kecil-Kecil Punya Karya, merupakan pelopor buku bacaan bermutu yang ditulis oleh anak-anak Indonesia. Dalam buku KKPK, tulisan yang diterbitkan adalah tulisan anak-anak usia 7-12 tahun, yang juga sesuai dengan pangsa pasar yang difokuskan. Berdasarkan hal yang dipaparkan tersebut, maka, tujuan kajian ini adalah mengkaji branding dari KPPK dalam perspektif peningkatan minat literasi anak. Dari telaah dengan metode penelitian kepustakaan yang dilakukan penulis, disimpulkan bahwa Penerbit Dar Mizan melalui buku KKPK telah membuat branding yang kuat sebagai pelopor penerbit buku yang memberikan wadah bagi anak-anak untuk menerbitkan secara visual tulisan mereka. Kesempatan untuk menuliskan hasil karya tulisan secara visual adalah dukungan terhadap kemampuan literasi seseorang, khususnya anak-anak. Dalam hal ini, Penerbit Dar Mizan, melalui buku KKPK telah meningkatkan minat dan kemampuan literasi anak-anak. KKPK telah menjadi media untuk meningkatkan kemampuan literasi anak-anak dengan lebih dini.
\end{abstract}

Kata Kunci: Branding, Serial KKPK, Literasi, Anak-anak

Abstract. Based on the results of a survey of literacy index published by Central Connecticut State of the University (CCSU) in March 2016 showed from 61 countries surveyed, Indonesia's literacy rankings are in the 60th sequence. The research also assessed the reading assessment score for children under the age of 18 , as quoted from page CCSU.edu (accessed 4/6/2017) shows that the ability of Indonesian children to understand the reading is also very low.

Children's literacy skills can be very high. That means, the family and the form of early childhood education have a very big influence on the high-low literacy ability of a child.

The publisher of Mizan through KKPK / Kecil-Kecil Punya Karya, is a pioneer of quality reading books written by Indonesian children. In KKPK's book, the writings published are children's writing from 7-12 years old, which also corresponds to a focused market share. Based on the point of view, the purpose of this study is to examine the branding of KPPK in the perspective of increasing the interest of children literacy. From the study of literature research methods conducted by the author, it is concluded that Dar Mizan Publisher through KKPK book has made a strong branding as a pioneer of book publishers that provides a container for children to publish their writing visually. The opportunity to write visual works is support for one's literacy skills, especially children. In this case, Dar Mizan Publisher, through KKPK book has increased interest and literacy ability of children. KKPK has become a medium to improve the literacy ability of children with earlier.

Keywords: Branding, KKPK Serial, Literacy, Children 
PENDAHULUAN

Hasil survey indeks literasi yang diterbitkan oleh Central Connecticut State of University (CCSU) pada Maret tahun 2016 memperlihatkan dari 61 negara yang disurvei, peringkat literasi Indonesia ada di uruta ke 60. Riset yang juga menilai reading assesment score untuk anak di bawah usia 18 tahun itu, seperti yang dikutip dari laman CCSU.edu (diakses 4/6/2017) menunjukkan bahwa kemampuan anak-anak Indonesia memahami bacaan juga sangat rendah.

Kemampuan literasi anak-anak bisa sangat tinggi. Itu artinya, keluarga dan bentuk pendidikan usia dini memberi pengaruh sangat besar terhadap tinggi-rendahnya kemampuan literasi seorang anak.

Pemerintah mulai menggalakkan program literasi ke sekolah-sekolah, tepatnya untuk usia pendidikan dasar. Selain membaca, kegiatan penunjang literasi lain, seperti bercerita, mendongeng, membedah buku dan masih banyak lagi dilaksanakan dalam program literasi tersebut.

Selain itu, dari komunitas penerbit buku, Penerbit DAR! Mizan membuat satu lini baru penerbitan buku, KKPK yang khusus menerbitkan buku-buku yang ditulis oleh anak-anak usia 7-12th. KKPK berhasil menjadi brand buku bacaan anak yang digemari oleh anak-anak usia SD (7-12th), yang membuat para penerbit lain pun ingin ikut merasakan manisnya kue tersebut, ikut meramaikan dunia bacaan anak yang pertama kali populer dengan nama Kecil-Kecil Punya Karya atau KKPK. Mizan sangat berbangga hati menjadi pelopor buku bacaan bermutu yang ditulis oleh anak-anak Indonesia. Berdasarkan hal yang dipaparkan tersebut, maka, tujuan kajian ini adalah mengkaji branding dari KPPK dalam perspektif peningkatan minat literasi anak.

\section{TELAAH PUSTAKA}

\section{Strategi Pemasaran}

Konsep marketing merupakan salah satu hal yang sangat penting dalam menjalankan sebuah usaha. Baik peluang usaha baru maupun usaha yang telah lama dirintis, baik usaha kecil maupun usaha yang telah berkembang sekalipun.
Semuanya membutuhkan konsep marketing untuk mengembangkan usaha yang dijalankan. Berbicara tentang konsep marketing, maka sesungguhnya kita sedang membicarakan bagaimana strategi pemasaran produk yang kita jual.

Hal itu pulalah yang dihadapi oleh usaha kecil yang saat ini banyak bermunculan. Merencanakan strategi pemasaran yang tepat untuk menarik minat konsumen pada usaha kecil masih sangatlah sulit. Salah satu cara yang dapat digunakan untuk mengembangkan usaha kecil tentunya dengan fokus pada strategi pemasaran.

Perusahaan tidak boleh memulai dengan menetapkan identitas merek. Perusahaan harus memulai dengan menetapkan tujuan merek. Tujuan merek menjawab pertanyaan tentang apa pekerjaan yang harus dicapai oleh merek untuk pembeli?

Sebagai contoh, semua mobil akan berjanji untuk membawa seseorang dari A ke B. Tidak ada perbedaan dalam pernyataan itu. Namun, jika janji Volvo adalah mendapatkan seseorang dari A ke B dengan keamanan maksimal, mobilnya telah membentuk kategori, Volvo telah memposisikan dirinya sebagai mobil yang aman. Atau pesaing baru mungkin memutuskan untuk menawarkan pelatihan dua jam gratis untuk berkendara yang aman. Pesaing ini melihat pekerjaannya sebagai mobil yang aman. Volvo mungkin merespons dengan merancang mobilnya agar memiliki sistem pengereman otomatis sehingga mobil Volvo akan berhenti atau melambat karena terlalu dekat dengan mobil lain dan dengan demikian menjadi lebih aman.

Perusahaan perlu menggunakan
positioning dan diferensiasi untuk mengkomunikasikan tujuan merek dan pada akhirnya memperkaya identitas merek. David Aaker, seorang ahli dalam membangun merek, telah merekomendasikan agar merek tidak hanya mendefinisikan tujuan fungsionalnya, pekerjaan yang akan dilakukan, tetapi juga untuk mengekspresikan tujuan merek yang lebih tinggi. Tujuan yang lebih tinggi menunjukkan manfaat emosional dan sosial yang berasal dari memilih merek itu. Tujuan fungsional Coca Cola adalah 
untuk "menghilangkan rasa haus dengan selera yang baik." Jika itu adalah ruang di mana Coca Cola ingin melangkah lebih jauh daripada hanya mengantarkan kebahagiaan dengan meminum Coke. Coca Cola bisa beralih menciptakan Disneyland dan menghibur Coca Cola akan bersaing dengan Disney.

Berikut model konseptual 6 langkah

PHILIP KOTLER'S 6-STEP BRANDING CONCEPTUAL MODEL

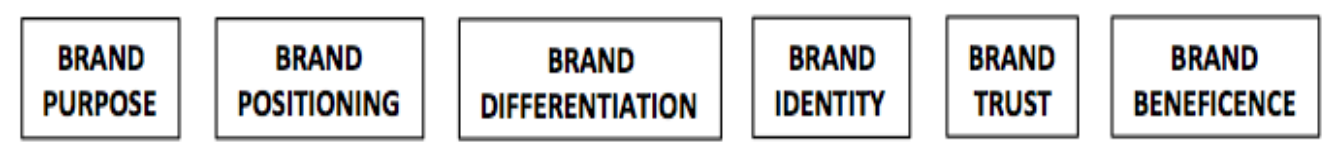

Pada langkah kelima dan keenam untuk membawa dua pertimbangan tambahan dalam membentuk merek yang layak, menarik dan berkelanjutan. Merek membutuhkan kepercayaan merek sehingga pelanggan akan percaya bahwa merek tersebut akan memberikan apa yang diklaimnya. Pelanggan Apple percaya bahwa ponsel Apple dan jam tangan Apple mereka akan menyampaikan apa yang diklaim perusahaan tersebut.

Pertimbangan terakhir adalah apakah merek tersebut memberi brand beneficence. Sebagai contoh, Marlboro adalah merek rokok yang paling populer. Ini memberikan rasa dan kepuasan yang tinggi. Tapi itu juga bisa menyebabkan serangan jantung, kerusakan hati dan keburukan pada orang lain di sekitar asap. Gulfstream dapat memberikan perjalanan yang menyenangkan dan menyenangkan bagi satu CEO namun menghasilkan lebih banyak polusi dan kerusakan iklim per orang daripada penerbangan penumpang penuh dalam pesawat Boeing. Perusahaan dalam masyarakat bebas dapat dengan leluasa memutuskan apa yang ingin mereka buat dan jual tapi mereka harus mempertimbangkan apakah merek tersebut memiliki masalah dengan keuntungan dan apakah ini pada akhirnya akan merugikan merek. Pertimbangkan bahwa industri makanan kita membuat penggunaan gula, lemak, dan garam yang berat, semuanya mengarah pada obesitas dan penyakit tertentu. Karena semakin banyak konsumen yang menyadari dampak buruk ini, mereka mungkin mundur dari penggunaan produk atau merek. Perusahaan yang bertanggung jawab secara sosial perlu menetapkan penawarannya untuk meminimalkan efek buruk dari pribadi atau sosial dari penawaran merek mereka.

Pemasar perlu menargetkan tidak hanya pikiran pelanggan tapi juga hati dan kesejahteraan mereka. Model konseptual ini sangat relevan untuk pemasaran di era pertumbuhan media digital dan sosial ini. Kita hidup di era pemberdayaan konsumen yang dipimpin oleh banyak informasi dan komunitas jaringan. Merek harus memiliki posisi berdiri-diferensiasi-integritas-integritas yang jelas dan konsonan. Merek yang tidak autentik tidak akan bertahan ketika word-ofmouth menjadi media periklanan baru dan konsumen lebih mengandalkan kenalan di komunitas jaringan mereka daripada pada apa yang perusahaan katakan dan beriklan.

Selain itu terdapat beberapa hal yang harus diperhatikan dalam menyusun strategi pemasaran yaitu sebagai berikut :

1. Konsistensi: Dengan adanya konsistensi terhadap semua area marketingnya, dapat membantu mengurangi biaya marketing dan meningkatkan efektivitas penciptaan merek.

2. Perencanaan: Perencanaan konsep marketing yang akan dijalankan usaha kecil sangat mempengaruhi banyaknya pelanggan yang diperoleh. Oleh karena itu luangkan waktu untuk merencanakan strategi marketing, anggaran marketing, serta konsep lainnya yang berhubungan dengan pemasaran.

3. Strategi: Strategi merupakan dasar untuk kelanjutan kegiatan marketing 
yang telah direncanakan, misalnya siapa target pasar, bagaimana usaha kecil membidik pelanggan, dan bagaimana cara menjaga konsumen yang ada sebagai pelanggan tetap.

4. Target Market: Mendefinisikan secara tepat pangsa pasar yang dituju, dengan memilih satu atau lebih dari segmen pasar yang akan dimasuki. Target pasar yang jelas akan membuat konsep marketing lebih mudah dilaksanakan.

5. Anggaran: Menghitung anggaran marketing merupakan bagian yang berat dan membutuhkan keakuratan hasil hitungan. Dari anggaran yang dibuat, dapat dipersipkan dana yang akan dibutuhkan untuk pemasaran. Biasanya usaha kecil membuat anggaran dengan tidak terlalu akurat, sehingga terjadi pemborosan.

6. Marketing Mix: Marketing mix biasanya dijelaskan sebagai produk, harga, tempat, dan promosi. Sebagai pengusaha kecil, perlu memutuskan dengan spesifik produk (atau jasa), harga yang sesuai, dimana dan bagaimana Anda akan mendistribusikan produk Anda, dan bagaimana orang lain dapat mengetahui tentang produk yang ditawarkan.

7. Website: Saat ini bisnis apapun termasuk usaha kecil usahakan memiliki website, karena hampir $60 \%$ konsumen datang dari informasi dari internet. Sehingga informasi produk melalui website pun sangat mendukung peningkatan jumlah pelanggan yang tertarik dengan produk Anda.

8. Branding: Branding adalah bagaimana konsumen menerima produk dan perusahaan yang membuat produk tersebut. Terkadang usaha kecil selalu melupakan kebutuhan brand atau pengenalan gambar, logo, bahkan produk yang usaha kecil hasilkan.

9. Promosi dan iklan: Promosi dan iklan merupakan konsep marketing yang harus dipertimbangkan pada berbagai bsnis dan produk, termasuk pada usaha kecil. Promosi dan iklan yang baik akan menghasilkan pengakuan brand yang efektif hingga mampu meningkatkan penjualan.

10. Customer Relationship Management: Pengelolaan hubungan dengan pelanggan yang tepat menjadi salah satu hal penting untuk menciptakan konsumen yang loyal dan konsisten. Misalnya saja dengan membuat kartu membership, dan memberikan potongan harga tertentu bagi para member.

Keller (dalam Tjiptono 2005) mendefinisikan merek sebagai produk yang mampu memberikan dimensi tambahan yang secara unik membedakannya dari produkproduk lain yang dirancang untuk memuaskan kebutuhan serupa. Perbedaan tersebut bisa bersifat rasional dan tangible (terkait dengan kinerja produk dari merek bersangkutan) maupun simbolik, emosional dan intangible (berkenaan dengan representasi merek). Dapat disimpulkan bahwa secara teknis ketika sebuah perusahaan membuat nama dan logo maka perusahaan tersebut telah menciptakan merek. Namun tidak hanya itu, merek bukan hanya sekedar simbol namun juga merupakan elemen yang mampu membedakan suatu produk dengan produk-produk lain.

\section{Literasi}

Literasi mungkin telah menjadi istilah yang familiar bagi banyak orang. Namun tidak banyak dari mereka yang memahami makna dan definisinya secara jelas. Sebab memang Literasi merupakan sebuah konsep yang memiliki makna kompleks, dinamis, terus ditafsirkan dan didefinisikan dengan beragam cara dan sudut pandang. Berangkat dari sini, maka perlu kiranya diuraikan apa sebenarnya makna dari Istilah Literasi itu. Secara tradisional, arti literasi adalah kemampuan membaca, menulis, dan berhitung aritmatika (calistung). Diperdalam lagi, makna literasi adalah kemampuan untuk mengidentifikasi, memahami, menafsirkan, membuat, berkomunikasi, dan menghitung dengan menggunakan bahan cetak dan tulisan serta kemampuan untuk mengekspresikan pikiran, perasaan, dan gagasan. 
UNESCO mendefinisikan literasi sebagai kemampuan untuk mengidentifikasi, memahami, menafsirkan, menciptakan, berkomunikasi dan menghitung, menggunakan materi cetak dan tulisan yang terkait dengan berbagai bidang. Melibatkan sebuah rangkaian pembelajaran yang memungkinkan individu untuk mencapai tujuan mereka untuk mengembangkan pengetahuan dan potensi mereka dan untuk berpartisipasi sepenuhnya dalam masyarakat mereka dan masyarakat luas.

Contoh dari literasi adalah kemampuan berbahasa yang lengkap menyangkut aspek-aspeknya, mulai dari tata bahasa, teknik berbahasa, fonetik, dan lainlain. Termasuk di sini kemampuan menguasai bahasa asing. Contoh lain adalah kemampuan menulis sesuai kaidah bahasa, sastra, atau aturan penulisan dokumen.

Menurut kamus online MerriamWebster, Literasi berasal dari istilah latin 'literature' dan bahasa inggris 'letter'. Literasi merupakan kualitas atau kemampuan melek huruf/aksara yang di dalamnya meliputi kemampuan membaca dan menulis. Namun lebih dari itu, makna literasi juga mencakup melek visual yang artinya "Kemampuan untuk mengenali dan memahami ide-ide yang disampaikan secara visual (adegan, video, gambar)." Selain itu, literasi adalah kemampuan seseorang dalam mengolah dan memahami informasi saat melakukan proses membaca dan menulis. Literasi memerlukan serangkaian kemampuan kognitif, pengetahuan bahasa tulis dan lisan, pengetahuan tentang genre dan kultural.

Istilah literasi atau dalam bahasa Inggris literacy berasal dari bahasa Latin literatus, yang berarti "a learned person" atau orang yang belajar. Dalam bahasa Latin juga dikenal dengan istilah littera (huruf) yang artinya melibatkan penguasaan sistem-sistem tulisan dan konvensi-konvensi yang menyertainya.

National Institute for Literacy, mendefinisikan Literasi sebagai "Kemampuan individu untuk membaca, menulis, berbicara, menghitung dan memecahkan masalah pada tingkat keahlian yang diperlukan dalam pekerjaan, keluarga dan masyarakat." Definisi ini memaknai Literasi dari perspektif yang lebih kontekstual. Dari definisi ini terkandung makna bahwa definisi Literasi tergantung pada keterampilan yang dibutuhkan dalam lingkungan tertentu.

Di lain sisi, Education Development Center (EDC) menyatakan bahwa Literasi lebih dari sekedar kemampuan baca tulis. Namun lebih dari itu, Literasi adalah kemampuan individu untuk menggunakan segenap potensi dan skill yang dimiliki dalam hidupnya. Dengan pemahaman bahwa literasi mencakup kemampuan membaca kata dan membaca dunia.

Sementara menurut UNESCO, pemahaman orang tentang makna literasi sangat dipengaruhi oleh penelitian akademik, institusi, konteks nasional, nilai-nilai budaya, dan juga pengalaman. Pemahaman yang paling umum dari literasi adalah seperangkat keterampilan nyata, khususnya keterampilan kognitif membaca dan menulis yang terlepas dari konteks di mana keterampilan itu diperoleh dan dari siapa memperolehnya.

UNESCO menjelaskan bahwa kemampuan literasi merupakan hak setiap orang dan merupakan dasar untuk belajar sepanjang hayat. Kemampuan literasi dapat memberdayakan dan meningkatkan kualitas individu, keluarga, masyarakat. Karena sifatnya yang "Multiple Effect" atau dapat memberikan efek untuk ranah yang sangat luas, kemampuan literasi membantu memberantas kemiskinan, mengurangi angka kematian anak, pertumbuhan penduduk, dan menjamin pembangunan berkelanjutan, dan terwujudnya perdamaian. Buta huruf, bagaimanapun, adalah hambatan untuk kualitas hidup yang lebih baik.

Saat ini, Istilah Literasi sudah mulai digunakan dalam arti yang lebih luas, seperti Literasi Informasi, literasi komputer, dan literasi sains yang kesemuanya itu merujuk pada kompetensi atau kemampuan yang lebih dari sekedar kemampuan baca-tulis. Hanya saja, memang pemahaman yang paling umum 
mengenai literasi yaitu kemampuan membaca dan menulis.

Seseorang melek huruf (bisa baca-tulis) mampu memahami semua bentuk komunikasi yang lain. Implikasi dari kemampuan literasi yang dia miliki ialah pada pikirannya. Literasi melibatkan berbagai dasar-dasar kompleks tentang bahasa seperti fonologi (melibatkan kemampuan untuk mendengar dan menginterpretasikan suara), arti kata, tata bahasa dan kelancaran dalam setidaknya satu bahasa komunikasi. Keterampilan ini menentukan tingkat yang dicapai oleh seorang individu.

Literasi memang tidak bisa dilepaskan dari bahasa. Seseorang dikatakan memiliki kemampuan literasi apabila ia telah memperoleh kemampuan dasar berbahasa yaitu membaca dan menulis. Jadi, makna dasar literasi sebagai kemampuan baca-tulis merupakan pintu utama bagi pengembangan makna literasi secara lebih luas. Dan cara yang digunakan untuk memperoleh literasi adalah melalui PENDIDIKAN.

Pendidikan dan kemampuan literasi adalah dua hal yang sangat penting dalam hidup kita. Kemajuan suatu negara secara langsung tergantung pada tingkat melek huruf di negara tersebut. Oleh karena itulah, orang berpendidikan diharapkan untuk melakukan tugasnya dengan baik

\section{Perkembangan Literasi}

Awal pengertian literasi secara sempit adalah untuk kemampuan dalam hal membaca, namun kemudian ditambahkan juga dengan kemampuan menulis. Pada abad pertengahan, sebutan literatus ditujukan kepada orang yang dapat membaca, menulis dan bercakap-cakap dalam bahasa Latin. Carlo M. Cipolla sejarawan Italia menggunakan istilah "semi-iliterate" bagi mereka yang dapat membaca tetapi tidak dapat menulis. Dalam perkembangan waktu, pengertian literasi bukan hanya berkaitan dengan keaksaraan atau bahasa, namun berkembang menjadi konsep fungsional pada dasawarsa 1960-an yaitu literasi berkaitan dengan berbagai fungsi dan keterampilan hidup (Gomez, 2008).

Konsep Literasi dipahami sebagai seperangkat kemampuan mengolah informasi, jauh di atas kemampuan menganalisa dan memahami bahan bacaan. dengan kata lain, literasi bukan hanya tentang membaca dan menulis, tetapi juga mencakup bidang lain, seperti ekonomi, matematika, sains, sosial, lingkungan, keuangan, bahkan moral (moral literacy). Serbuan teknologi informasi yang semakin gencar, dalam dunia pendidikan menggunakan istilah multiliterasi, bahkan multiliterasi kritis (critical multiliteracies). Secara sederhana dapat dikatakan, istilah ini menunjuk pada kondisi mampu secara kritis menggunakan berbagai wahana dalam berkomunikasi.

Literasi dianggap merupakan inti kemampuan dan modal utama bagi siswa maupun generasi muda dalam belajar dan menghadapi tantangan-tantangan masa depan. Pembelajaran literasi yang bermutu adalah kunci dari keberhasilan siswa.di masa depan. Untuk itu dibutuhkan pembelajaran literasi yang bermutu pada semua mata pelajaran.oleh semua guru yang dianggap sebagai guru literasi (teachers of literacy).

Winnipeg.com

mengemukakan, ada lima cara yang terbukti efektif mengembangkan kemampuan literasi seorang anak. Proses pembelajarannya mestilah dimulai sejak bayi. Lima cara itu adalah:

1. Bicara

Rutin ngobrol dengan anak akan membantu mengembangkan kemampuan berbahasa dan menstimulasi otaknya. Sejak anak masih bayi, rajin-rajinlah bicara apa saja dengannya.

2. Menyanyi

Lagu anak-anak umumnya berima. Rima sangat baik untuk melatih kepekaan berbahasa. Semakin baik syair dan rima sebuah lagu, semakin peka otaknya mengindera bahasa. Indonesia punya cukup banyak lagu-lagu anak-anak yang indah dan berima, seperti Balonku, Burung Kutilang, Pohon Cemara dan Naik Delman. Selain itu, Seperti yang dikutip dari Raisingchildren.net.au (3/4/2017) orang tua juga bisa melakukan permainan rima kata. Permainan ini akan melatih anak mendengar dengan cermat bagaimana sebuah kata berbunyi. Permainan ini bisa dimainkan dimana saja 
dan kapan saja. Saat Anda melontarkan sebuah kata, misalnya delman, ajak anak untuk menyebut kata yang mirip rimanya, seperti teman atau zaman.

3. Membacakan buku cerita atau mendongeng

Rutin membacakan buku cerita untuk anak akan membuat mereka terlatih menjadi pembaca yang baik ketika besar nanti. Luangkan waktu lima menit menjelang tidur malam untuk membacakan cerita-cerita menarik untuk mereka. Biarkan anak-anak melihat gambar dan huruf di buku tersebut.

4. Menulis

Setelah anak berusia 4 atau 5 tahun, ajaklah mereka menulis. Kegiatan ini akan membuat anak belajar untuk memindahkan bunyi huruf yang mereka dengar ke dalam simbol-simbol. Gunakanlah media pelajaran yang menarik.

5. Bermain

Bermain ternyata merupakan cara efektif untuk mengembangkan kemampuan literasi anak-anak. Ketika mereka melakukan permainan imajinatif semacam main masak-masakan, dokter-dokteran, dan yang semacamnya, tanpa sadar mereka akan berlatih menyesuaikan kosa kata sesuai profesi atau permainan yang dijalani. Manfaat lainnya, mereka juga akan pelan-pelan mempelajari dunia tempat mereka tinggal.

Di masa sekarang, pendidikan literasi gencar dilakukan oleh para praktisi pendidikan

untuk mencetak individu yang tidak hanya cerdas dalam bidang akademik, namun juga memiliki pola pikir kritis dan logis. Praktiknya tentu saja tidak harus terpaku pada pembelajaran di sekolah. Orang tua di rumah pun perlu turut andil dalam menanamkan pendidikan literasi pada anak-anak mereka mulai dari usia prasekolah. Tujuan utamanya bukan hanya menekankan pada kemampuan anak untuk membaca atau menulis. Kedua jenis kemampuan tersebut sebenarnya hanya menjadi landasan bagi tujuan yang lebih luas, yakni membentuk generasi yang mampu berpikir kritis dalam menyikapi informasi.

Khusus untuk anak usia dini atau prasekolah, pendidikan literasi penting dilakukan karena memiliki banyak manfaat. Berikut adalah beberapa alasan pentingnya penerapan pendidikan literasi sejak dini.:

Melatih kemampuan dasar anak untuk membaca, menulis, dan menghitung

Pendidikan literasi untuk anak usia dini bisa dimulai dengan kebiasaan membacakan buku cerita atau dongeng pada anak secara rutin. Meski terkesan seperti kegiatan sederhana, membacakan buku pada anak adalah tahap awal mengenalkan mereka pada dunia literasi. Sebuah survei yang dilakukan oleh salah satu divisi Kementerian Pendidikan Amerika Serikat menunjukkan bahwa balita yang terbiasa dibacakan buku oleh orang tua mereka bisa lebih cepat mengenal abjad. Survei lainnya memperlihatkan keberhasilan balita dalam tahapan literasi awal, seperti menulis namanya sendiri,membaca atau berinteraksi dengan buku, serta menghitung hingga bilangan 20.

Mengembangkan kemampuan berpikir kritis

Tingkat literasi yang tinggi akan berbanding lurus dengan kemampuan seseorang untuk menerima, mengolah, dan menyikapi setiap informasi yang diterimanya. Oleh karena itu, pendidikan literasi yang diterapkan pada anak usia dini berperan sebagai pondasi bagi mereka untuk bisa memiliki kemampuan berpikir kritis dan logis ketika dihadapkan dengan berbagai situasi. Pola pikir kritis diperlukan sebagai investasi yang akan berguna saat anak mulai memasuki dunia masyarakat yang sebenarnya di masa mendatang.

Mempersiapkan anak untuk memasuki dunia $\underline{\text { sekolah }}$

Mengenalkan poin-poin utama dalam pendidikan literasi pada anak prasekolah akan membantu mereka mempersiapkan diri saat memasuki dunia sekolah. Perkembangan sosial-emosional, kognitif, bahasa, dan literasi adalah sejumlah aspek penting yang harus dimiliki anak. Aspek-aspek tersebut saling 
berhubungan satu sama lain dan dapat didukung dengan penerapan pendidikan literasi pada usia dini. Tahapan literasi awal yang meliputi bahasa lisan dan tulisan serta pengetahuan mengenai angka dan huruf menjadi salah satu kunci keberhasilan anak prasekolah dalam membaca. Kemampuan ini akan bisa diandalkan ketika mereka mulai mendapatkan pembelajaran di sekolah.

Perkembangan literasi yang baik berkolerasi dengan prestasi akademik

Pendidikan literasi yang telah diterapkan sejak dini akan memberikan dampak positif terhadap prestasi akademik seorang anak. Praktik pengenalan literasi awal dengan membacakan buku pada anak terbukti dapat membuat anak lebih sukses dalam bidang akademik. Hal tersebut dikarenakan anak yang telah terbiasa dikenalkan dengan dunia literasi memiliki kemampuan belajar dan berkomunikasi yang lebih baik daripada anak lainnya yang belum mendapatkan pengenalan mengenai literasi. Kemampuan akademik tersebut juga ditambahkan dengan kemampuan memecahkan masalah logis seperti dalam pengerjaan soal-soal matematika.

\section{METODE PENELITIAN}

\begin{abstract}
Metode penelitian yang dilakukan adalah dengan penelitian kepustakaan. Penelitian kepustakaan adalah adalah penelitian yang dilakukan hanya berdasarkan atas karya tertulis. Termasuk di dalamnya hasil penelitian, baik yang sudah maupun belum dipublikasikan. Data yang diambil berupa data sekunder, yang diunduh dari internet melalui situs terkait.
\end{abstract}

\section{HASIL DAN PEMBAHASAN}

Kecil-Kecil Punya Karya (KKPK) adalah sebuah lini Penerbit DAR! Mizan yang khusus menerbitkan buku-buku yg ditulis oleh anak-anak usia 7-12th. Nama Kecil-Kecil Punya Karya (KKPK) diberikan oleh Kak Andi Yudha Asfandiyar. KKPK yang awal penerbitannya merupakan sebuah idealisme, untuk menampung karya dari anakanak Indonesia, terbit mulai akhir 2003. Judul pertamanya "Kado Untuk Ummi", berbentuk novel ditulis oleh Sri Izzati yang waktu itu usianya 7 tahun. Menyusul kemudian
Abdurrahman Faiz (putra Helvi T. Rosa), menerbitkan kumpulan Puisinya. Puisinya yang terkenal waktu itu adalah Surat Untuk Presiden (Masa Presiden Megawati). Kementerian Pendidikan Indonesia, sejak 2010, selalu memberikan dukungan untuk acara Konferensi Penulis Cilik Indonesia (KPCI). Seluruh Penulis Cilik, semuanya tergabung dalam Komunitas Penulis Cilik Indonesia.

Berdasarkan telaah pustaka, berikut ini adalah strategi pemasaran yang dilakukan oleh Penerbit Dar Mizan.

\section{Target Market}

Mendefinisikan secara tepat pangsa pasar yang dituju, dengan memilih satu atau lebih dari segmen pasar yang akan dimasuki. Target pasar yang jelas akan membuat konsep marketing lebih mudah dilaksanakan. Pada KKPK target pangsa pasar yang dituju adalah satu fokus, yakni anak-anak usia 7-12 tahun.

\section{Marketing Mix}

Marketing mix biasanya dijelaskan sebagai produk, harga, tempat, dan promosi. Pada KKPK, Penerbit Dar Mizan menetapkan spesifik produk buku yang merupakan hasil karya dari anakanak usia 7-12 tahun dengan segmen pasar anak usia yang sama. Ini sekaligus merupakan keunikan/ differences dari produk buku KKPK.

\section{Website}

Saat ini bisnis apapun termasuk usaha kecil usahakan memiliki website, karena hampir $60 \%$ konsumen datang dari informasi dari internet. Sehingga informasi produk melalui website pun sangat mendukung peningkatan jumlah pelanggan yang tertarik dengan produk yang ditawarkan perusahaan. KKPK melakukan strategi ini dengan membangun web Rumah KKPK.com

\section{Branding}

Branding adalah bagaimana konsumen menerima produk dan perusahaan yang membuat produk tersebut. KKPK sudah menjadi merek dengan branding khusus yakni buku anak dengan penulis dari anak-anak sendiri.

\section{Promosi dan iklan}


Promosi dan iklan merupakan konsep marketing yang harus dipertimbangkan pada berbagai bsnis dan produk, termasuk pada usaha kecil. Promosi dan iklan yang baik akan menghasilkan pengakuan brand yang efektif hingga mampu meningkatkan penjualan. Selain melalui web Rumah KKPK.com, KKPK juga melakukan promosi melalui tokomizan online. Kegiatan promosi juga dilakukan melalui tokopedia.

6. Customer Relationship Management

Pengelolaan hubungan dengan pelanggan yang tepat menjadi salah satu hal penting untuk menciptakan konsumen yang loyal dan konsisten. KKPK rutin mengadakan Konferensi Penulis Cilik Indonesia (KPCI). Seluruh Penulis Cilik, semuanya tergabung dalam Komunitas Penulis Cilik Indonesia.

Dengan kuatnya branding KKPK sebagai produk buku dari Penerbit Mizan, KKPK menjadi pelopor buku bacaan bermutu yang ditulis oleh anak-anak Indonesia. Implikasi dari kemampuan literasi yang dia miliki ialah pada pikirannya. Literasi melibatkan berbagai dasar-dasar kompleks tentang bahasa seperti fonologi (melibatkan kemampuan untuk mendengar dan menginterpretasikan suara), arti kata, tata bahasa dan kelancaran dalam setidaknya satu bahasa komunikasi. Keterampilan ini menentukan tingkat yang dicapai oleh seorang individu. Semua kemampuan ini dapat dituangkan melalui tulisan anak-anak pada buku KKPK.

UNESCO mendefinisikan literasi sebagai kemampuan untuk mengidentifikasi, memahami, menafsirkan, menciptakan, berkomunikasi dan menghitung, menggunakan materi cetak dan tulisan yang terkait dengan berbagai bidang. Melibatkan sebuah rangkaian pembelajaran yang memungkinkan individu untuk mencapai tujuan mereka untuk mengembangkan pengetahuan dan potensi mereka dan untuk berpartisipasi sepenuhnya dalam masyarakat mereka dan masyarakat luas.
Literasi merupakan kualitas atau kemampuan melek huruf/aksara yang di dalamnya meliputi kemampuan membaca dan menulis. Namun lebih dari itu, makna literasi juga mencakup melek visual, selan itu literasi adalah kemampuan seseorang dalam mengolah dan memahami informasi saat melakukan proses membaca dan menulis. Literasi memerlukan serangkaian kemampuan kognitif, pengetahuan bahasa tulis dan lisan, pengetahuan tentang genre dan kultural.

Penerbit Dar Mizan melalui buku KKPK telah membuat branding yang kuat sebagai pelopor penerbit buku yang memberikan wadah bagi anak-anak untuk menerbitkan secara visual tulisan mereka. Kesempatan untuk menuliskan hasil karya tulisan secara visual adalah dukungan terhadap kemampuan literasi seseorang, khususnya anak-anak. Dalam hal ini, Penerbit Dar Mizan, melalui buku KKPK telah meningkatkan minat dan kemampuan literasi anak-anak.

\section{SIMPULAN DAN SARAN}

Berdasarkan telaah yang dilakukan penulis, disimpulkan bahwa Penerbit Dar Mizan melalui buku KKPK telah membuat branding yang kuat sebagai pelopor penerbit buku yang memberikan wadah bagi anakanak untuk menerbitkan secara visual tulisan mereka. Kesempatan untuk menuliskan hasil karya tulisan secara visual adalah dukungan terhadap kemampuan literasi seseorang, khususnya anak-anak. Dalam hal ini, Penerbit Dar Mizan, melalui buku KKPK telah meningkatkan minat dan kemampuan literasi anak-anak. KKPK telah menjadi media untuk meningkatkan kemampuan literasi anak-anak dengan lebih dini.

\section{REFERENSI}

Kotler, Philip T. 2016 Marketing Management, 15th Edition. Northwestern University

ISBN-13: $\quad 9780133856460$

Bhola, Harban S., Sofía Valdivielso Gómez. Signposts to Literacy for Sustainable 
Redjeki Agoestyowati, Branding Serial KKPK: Tinjauan Pada Minat Literasi Anak-Anak

Development .UIL, 2008. ISBN 978-92-8201153-9

https://mayalestarigf.com/2017/06/12/limacara-mengembangkan-kemampuan-literasianak/

Pentingnya Pendidikan Literasi untuk Anak Usia Dini

http://www.educenter.id/pentingnyapendidikan-literasi-untuk-anak-usia-dini/

https://web.facebook.com/notes/kecil-kecilpunya-karya/tentang-kecil-kecil-punya-karyakpci/418986099943/? rdc=1\&_rdr

https://books.google.co.id/books?id=yxz24_fs $\underline{07 \mathrm{sC} \& p g=P R 14 \& \operatorname{lpg}=\mathrm{PR} 14 \& \mathrm{dq}=\text { branding }+\mathrm{p}}$ $\underline{\text { roduk+buku\&source }=\text { bl\&ots }=\text { nlyJ32LujL\&si }}$ $\mathrm{g}=\mathrm{XNyUi0vRE}-$

Os9_6O5_pFwb2pNyI\&hl=id\&sa=X\&ved $=0$ ahUKEwiUrvalmqfXAhWMvbwKHZgtBKs Q6AEIhQEwDA\#v=onepage $\& \mathrm{q}=$ branding $\% 2$ Oproduk\%20buku\&f=false

https://www.selasar.com/answer/8147/Apaka h-itu-literasi-Apa-saja-pembagian-dariliterasi-itu-sendiri-Dan-seperti-apa-contohnya

https://www.kanalinfo.web.id/2016/11/penger tian-literasi-dan-perkembangannya.html

http://literasi.jabarprov.go.id/baca-artikel954-apa-sih-literasi-itu.html 